
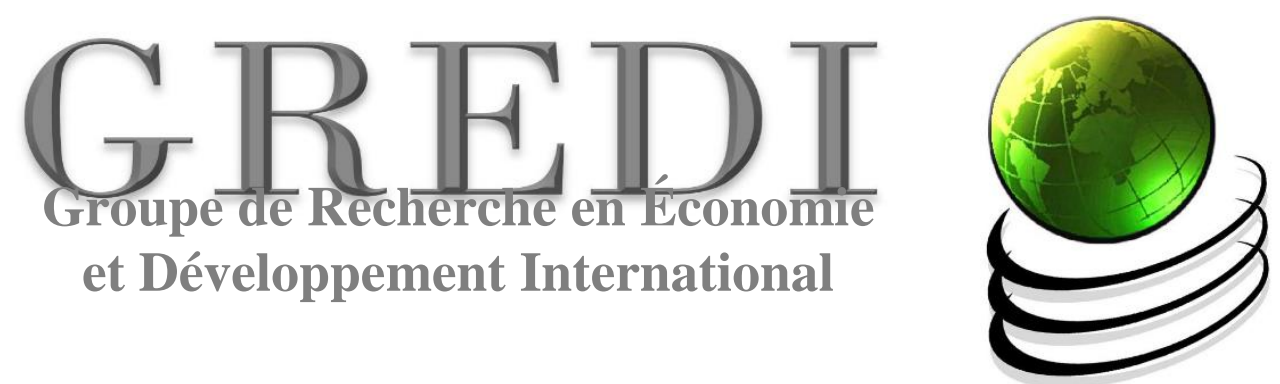

Cahier de recherche / Working Paper

19-01

\title{
Improving learning outcomes in Francophone Africa: More resources or improved efficiency?
}

\author{
Élisé Wendlassida MININGOU \\ Jean-Marc BERNARD \\ Medjy PIERRE-LOUIS
}




\title{
Improving learning outcomes in Francophone Africa: More resources or improved efficiency?
}

\author{
Élisé Wendlassida Miningou* ${ }^{* \dagger}$, Jean-Marc Bernard*, Medjy Pierre-Louis*
}

\begin{abstract}
The lack of resources is often highlighted as the most important correlate of poor learning outcomes in developing countries. However, increasing school resources may not necessarily drive better learning if resources are not properly translated into learning outcomes. The current paper investigates the efficient utilization of school resources to promote learning. Applying the Data Envelopment Analysis methodology, an efficiency analysis is performed using PASEC 2014 learning assessment that covers 10 francophone, West and Central African countries. This paper also tries to better understand to which extent efficiency plays a role in the relationship between school resources and learning outcomes. The results show that the efficiency of school resource utilization varies across countries and across schools within the same countries. The relationship between some of the key elements of school resources and learning is weak in the least efficient schools. This suggests that resources allocated to the low efficient schools should consider first addressing inefficiency issues. While efficiency drivers may vary depending on the country's specific contexts, findings show that students' absenteeism, implication of the community in school management, teaching time and school environment play a role in school efficiency.
\end{abstract}

Keywords: Education, Learning outcomes, Efficiency

JEL Codes: O15, I25

\footnotetext{
* World Bank Group, Global Partnership for Education, 1850 H Street, NW, Suite 650, Washington, DC, 20006, USA

† Corresponding author: eminingou@globalpartnership.org
} 


\section{Introduction}

Countries across the global south are increasingly making investments in education in response to the overwhelming evidence supporting its value to a nation's economic development. With the support of international development agencies (World Bank, Global Partnership for Education, UNESCO, etc.), and under the influence of the Millennium Development Goals (MDG) as well as the recent Sustainable Development Goals (SDG4), many African nations have been financially enabled to allocate resources to education and schooling. However, as the various political motives that continue to drive distribution of funding are coupled with complications in authority over educational financing, these precious resources are often managed inefficiently in developing contexts (Geo-Jaja, 2004 and Gershberg and Winkler,2004). This can result in cases wherein one region with fewer resources outperforms another region that was allotted significantly greater resources than its country counterparts. Such cases exemplify dilemmas of learning inefficiency when the learning outcomes of students do not positively align with the resources inputted into schools.

The lack of correlation between resources inputted and learning outcomes is alarming in many low-income contexts. The 2014 Global Education Monitoring (GEM) Report highlighted though many African nations have increased their spending on education over the past two decades, still only 2 out of 5 children achieve minimum learning proficiency standards upon reaching grade 4. The GEM report identifies the lack of highly trained, motivated teachers as a key source in the global discrepancy between resources and learning outcomes. ${ }^{3}$ In the specific context of African countries, data shows that resources alone may not drive significant improvement in learning outcomes in the presence of inefficiencies. As demonstrated by Figure 1 , there is no correlation between the public cost per primary age child and achievements in learning outcomes in select Africa countries. Some countries have relatively higher spending on primary education, but this is not translated into learning outcomes.

Figure 1 Public primary education spending per primary school age child and proportion of primary completers achieving minimum proficiency level in reading

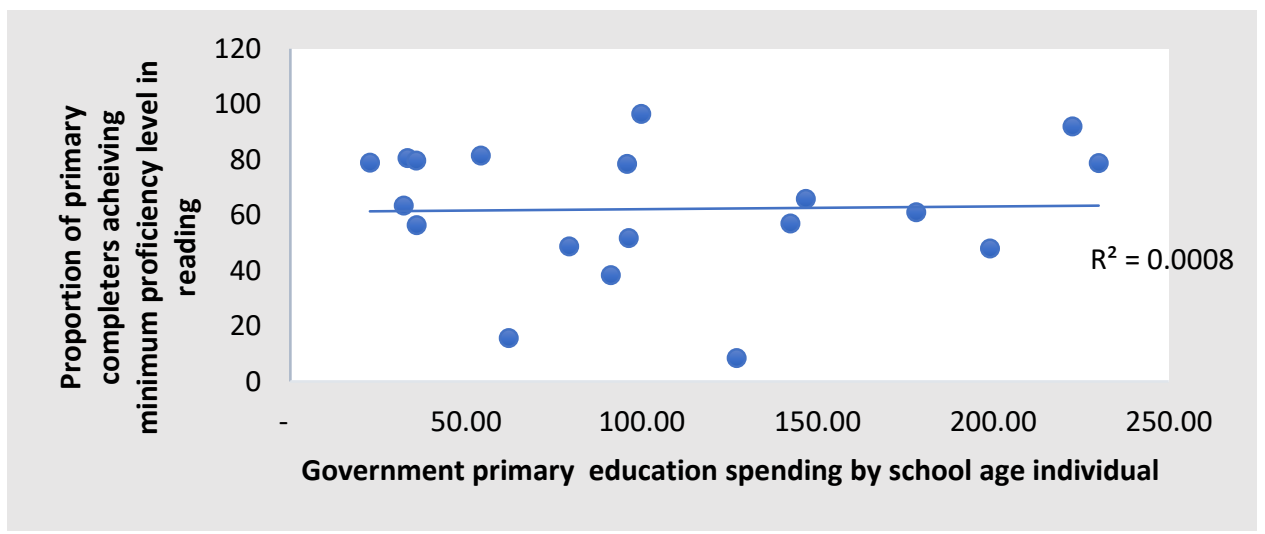

Source: Authors' compilations based on UIS and World Development Indicators

Studies in Africa specifically also highlighted the lack of correlation between education resources and learning. For instance, research out of South Africa suggests that this lack of correlation between resources and learning could be explained by the socio-economic status of students (Vanderbeg, 2008). Similarly, when school resources and achievement are evaluated for countries who participated in the second Southern and Eastern Africa Consortium for Monitoring Educational Quality (SACMEQ-II), it was found that not

${ }^{3}$ UNESCO (2014) 
only social background was associated with higher achievement when more quality resources were present, but also when school sizes were smaller, school days were longer, and repetition is less utilized to remediate students. These findings pointing to teacher quality, school size, and class time suggest that when resources are used efficiently, stronger learning outcomes are promoted (Lee and Zuze, 2011).

The lack of correlation between resources and learning outcomes at the macro level may be driven by the fact that some schools are facing some challenges in the way their resources are translated into learning. When analyzing the relationship between learning and school resources for the countries that participated in the PASEC 2014 regional assessment, it appears that the school level learning outcomes and resources inputted vary greatly (Figure 2). While there seems to be a weak correlation between resources and learning outcomes, some schools with approximately the same level of resources achieve different results. Patterns emerge from these data, showcasing differences in the ability to transform resources into learning outcomes. Certainly, resources are essential to learning. However, expansive resources do not necessarily produce improved outcomes when resources are not properly used.

Figure 2 Relationship between PASEC reading score and pedagogical resource index

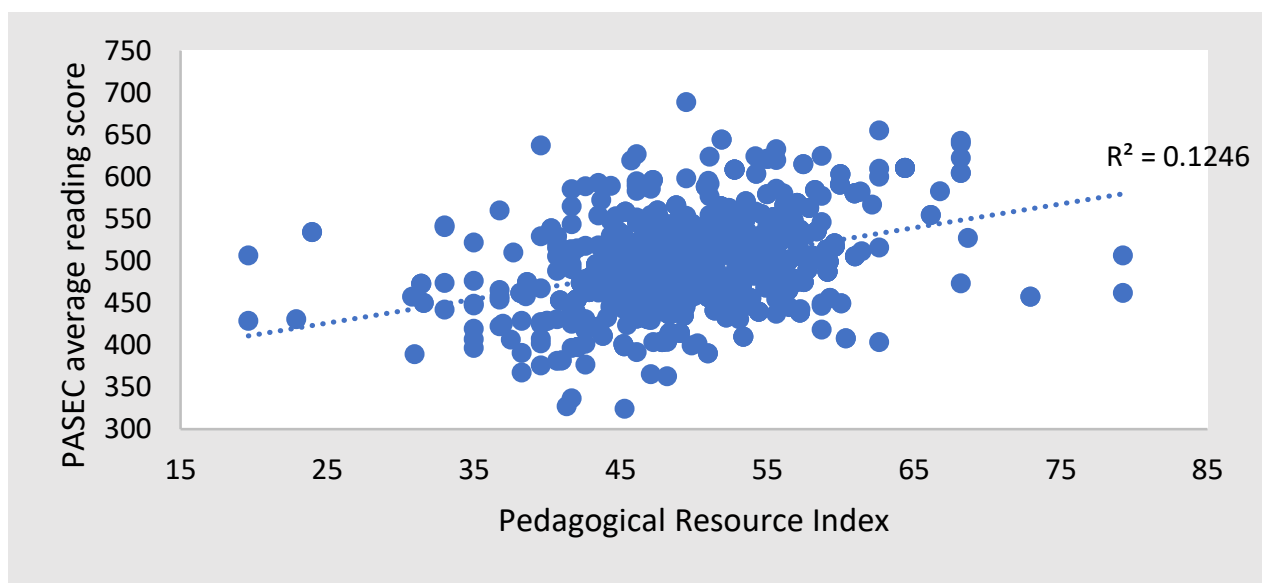

Source: Authors' compilations based PASEC 2014

Examining the 10 countries that participated in the 2014 PASEC assessment, the current study aims to better understand the relationship between school resources and learning outcomes in francophone Africa. It attempts to answer three main questions: (i) what is the level of efficiency in the use of school resources to promote learning outcomes? (ii) what are the characteristics of the highest/lowest efficient schools and what are the drivers of efficiency at school-level? (iii) what are the implications of school efficiency for education policies? The current paper endeavors to re-orient the on-going discussion on the determinants of learning outcomes towards the efficient use of resources at the school level. It strives to show that the relationship between resources and learning depends on the efficiency with which resources are translated into learning at school level.

The Data Envelopment Analysis (DEA) technique is applied to build an empirical frontier based on the sample that represents the best performing schools. Relative efficiency is then estimated for the other schools based on the distance to this empirical frontier. An econometric regression is later applied using Simar and Wilson (2007) double bootstrapping technique to investigate the determinants of efficiency. The results of this analysis suggest that the average, efficiency of school is 1.25 (or $80 \%$ ), showing that learning outcomes could have been $25 \%$ higher if all schools were relatively efficient. Although improving efficiency is a priority for all schools, it is especially important for schools with relatively low efficiency 
levels and low achievements in learning outcomes. Increasing the efficiency levels of low performing schools that already receive ample funding could result in an increase in students learning outcomes. Conversely, this evidence supports the idea that increasing school resources in low performing schools with high efficiency levels and low resource allocation could also be an effective way for improved learning outcomes. Overall, efficiency is mainly driven by supply side-factors showing that there is room for improving efficiency through targeted school-related policies.

The remaining of this paper will first discuss the literature on learning outcomes and the rationale behind examining efficiency as one of the main drivers for increased learning outcomes. Secondly, the DEA tool as well as the data, will be presented, followed by the findings from the analysis, showcasing the learning efficiency of PASEC 2014 countries. Finally, the paper will discuss the best strategies to improve learning outcomes when considering efficiency in resource utilization and the availability of resources.

\section{The learning crisis and the efficiency of education systems}

Researchers have long presented evidence strongly suggesting that investments in schooling can lead to more sustainable, economic development. From the late 1950s, Schultz explained that economic returns on investments in education were just as valuable as non-human capital (Schultz, 1961; Schultz, 1980). In his view, this was of particular salience to the developing world as he warned that non-human capital investments in the global south would have limited economic returns without the simultaneous investment in knowledge and skills. Since then, researchers have cemented these findings, confirming that the economic returns to education are substantial and similar in value to the returns on physical capital (Trostel et al., 2002; Psacharopoulos and Patrinos, 2004). The economic, social, and private returns to education are aligned with positive effects in sectors such as health and labor, showing that higher levels of education are associated with increased levels of health, productivity, and the rate of highly-skilled workers that enter and innovate labor markets (Cohn and Addison, 1998; OECD, 2018; Bloom et al., 2013).

One of the conditions necessary in enabling education investments to result in long term economic and social development is ensuring that years of schooling indeed translate to increased knowledge and capacity. In several papers, Hanushek argues that ensuring both basic and advanced skill development of a country's population promotes higher levels of GDP and the sustainability of stronger economies (Hanushek et al., 2008; Hanushek and Woessmann, 2008; Hanushek, 2013). Gyimah-Brempong (2012) highlights how the economic growth and GDP increases of many African nations are intricately tied to increases in the number of highly skilled workers present in the labor market. When evaluating the remarkable economic growth and development in the late 1900s of Singapore, Taiwan, and South Korea, otherwise known as the 'Tiger' economies, researchers emphasize the ability of the Asian Tigers to quickly upgrade the skills of their population from vocational to academic as these countries began producing goods and services of greater value (McGin et al, 1980; Ashton et al., 1999; Campos and Root, 1996; Ashton et al., 2002). Though Kuruvilla et al. (2002) discuss that Singapore's methods should not be merely transplanted to other developing contexts, one key tenant from their process that can be seen as universal to development is strengthening the connection between economic and skills or educational development.

As developing countries attempt to apply the strategy of utilizing education investments to promote economic progress, the level of human capital development seems largely unmoved. Children across the global south are increasingly obtaining access to schooling and primary school enrollment rates are currently at an all-time high (over $90 \%$ in developing countries alone ${ }^{i}$ ). Still, many children fail to achieve basic learning outcomes, with student learning metrics (as measured by standardized assessments) showcasing stagnant trends below grade-level in academic achievement (UNESCO, 2015; World Bank, 2017). 250 million primary school children are not meeting minimum proficiency standards, even though

over 50\% of this group has spent four or more years in school (UNESCO 2014; UNESCO, 2015; Birdsall 
et al., 2016). This phenomenon, better known as the 'learning crisis' is described as the emerging case wherein children across least developed countries (LDC) are failing to develop basic literacy skills after several years of schooling (Gove and Cvelich, 2011; Friedlander et al., 2018). In other words, more kids are going to school, but few are actually learning, and most are not learning enough.

If countries in the global south are unable to address the learning crisis, development in these contexts over the next few decades will likely not see the positive effects advised by economists. Beatty and Pritchett (2012) note that the average developing nation tends to score considerably below the average OECD norm and are at least several decades away from reaching OECD standards at the present rate of achievement. Such low levels of educational achievement can undermine economic growth, locking countries into cycles of slow economic progress, low employment rates, and increasingly fragile societies (Heyneman, 2003; UNESCO, 2013).

Many researchers have highlighted solutions for the learning crisis, though an underlying trend emerges pointing to the aspect of efficiency in education. The UNESCO Education for All (EFA) report (2014) emphasizes teacher quality as the key to addressing the learning crisis, calling on policy makers to support high quality instruction to improve the future learning prospects of students by recruiting better trained teachers, improving teacher training, allocating teachers effectively, and providing professional incentives tied to student performance. Other scholars discuss the importance of learning assessments to closely monitor student performance and provide important data useful in scaffolding learning throughout a student's schooling matriculation (Stiggins, 2002; William, 2011; Birdsall et al., 2016). Abagi and Odipo (1997) focus on the need to promote more "holistic school operation" to allocate funding toward teaching materials that enhance student learning. One could easily note that improvements in all of these areas of learning are necessary in facing the learning crisis (Michaelowa, 2001; Joel 1999). However, the strategy used to allocate education funding to the appropriate number and scale of inputs is key in ensuring that students have the necessary conditions available to promote achievement and skill development (Michaelowa, 2001).

Efficiency in education can be defined as the minimum cost balance between educational inputs and desired outputs (Hanushek, 1986). It is the relationship wherein resources are strategically inputted to enable more of the desired educational outcomes (Lockheed and Hanushek, 1988; Hanushek and Benson, 1994). Such resources can range across a wide variety of support including teacher quality and presence, school infrastructure and environment, curriculum development, or classroom materials (Witte and Lopez-Torres, 2017). Student outcomes can include outputs such as student achievement and test scores, enrollment, dropout, and graduation rates, or starting salary after school completion (Witte and Lopez-Torres, 2017).

Studies examining school efficiency present conflicting results, with some papers suggesting that resources may not result in any difference in student performance while others find that certain resources can have a considerable impact on student outcomes (Vegas and Coffin, 2017). Hanushek (1986) found that there was no significant relationship between school resources and student outcomes. He later reaffirmed his doubts by explaining the unlikeliness of even efficient use of increased inputs resulting in improved outputs (Hanushek, 1994). In a review of efficiency in education spending of 20 European countries, Agasisti (2014) found that underwhelming student achievement results in many wealthy countries are often disproportionate to the significant educational investments made per student. Conversely, key inputs such as learning materials, teacher quality, and instructional time have been found to have positive effects on student outcomes in low-income countries (Fuller and Clarke, 1994; Glewwe et al., 2011). Michaelowa (2001) expands upon the importance of textbooks and teacher quality in her study, stating that all education systems should make it a priority to allocate funding to these inputs to promote efficiency.

Despite the inconclusive literature on the impact of school resources on student outcomes, an underlying consensus emerges that suggests school inefficiencies could be linked to poor learning. Vegas and Coffin 
(2017) find positive effects on mean student learning outcomes (as measured by the PISA Mathematics test) below a spending threshold of $\$ 8000$ per student and diminishing effects above the threshold. Pritchett and Filmer (1999) support these findings, outlining that a school with high efficiency and high resources will out-perform (with diminishing effects) a school with the same level of efficiency and lower resources. This would intuitively suggest the inverse-- schools with the same resources and varying levels of efficiency would have varying levels of performance. Likewise, schools that operate below the frontier of efficiency experience inefficiencies that could be negatively affecting student outcomes.

Many researchers have investigated the effects of inefficiencies on learning using the DEA method. For example, Perleman and Santin (2011) employed a DEA approach to evaluate Spanish PISA results for education efficiency and found a considerable amount of variance in student performance could be explained by school and student inefficiencies. Essid et al., (2013) utilized the DEA method to evaluate the scale efficiency of Tunisian high schools and found that small school size was associated with more inefficiencies and poorer learning outcomes compared to larger school sizes. This paper will add to the existing literature through applying the DEA method to evaluate the efficiency of schools in the use of their resources to deliver learning, in 10 francophone Africa countries.

\section{Measuring school efficiency: A frontier approach}

As already mentioned, the purpose of this study is to understand how efficient the utilization of school resources is, to deliver quality education. It also aims to understand the relationship between school resources and learning outcomes when schools are efficient and inefficient. To achieve this goal, efficiency is first measured using DEA. An econometric technique is later applied to investigate the relationship between school inputs and learning outcomes in two categories of schools: the group of 'highest inefficiency' schools and the group of 'lowest inefficiency' schools.

\section{The Data Envelopment Analysis methodology}

The current paper suggests investigating the technical efficiency of schools in francophone Africa. ${ }^{4}$ Technical efficiency can be defined as the best observed practice in the reference set or comparison group (Farrell, 1957; Charnes et al. 1985, 1986). In the context of quality education service delivery, a technically efficient school can be defined as the one that achieves the highest learning outcomes for their students with the least possible amount of resources. The most efficient schools have good practices that allow them to make proper use of school inputs to produce the maximum possible outputs.

There exists a variety of efficiency measurement tools of which frontier approaches are the most commonly used in the literature. They are based on the construction of a production or a cost frontier and a comparison of each unit's inputs or outputs with their optimal values given by the frontier. Depending on the distance between the inputs/outputs and their optimal values, an efficiency score is given to each production unit. In the case of the current study, a production frontier must be built based on the sample. There are two main approaches for building this production frontier: parametric and non-parametric frontier approaches. While parametric approaches require assumptions regarding the production function, non-parametric methods use weaker assumptions.

\footnotetext{
${ }^{4}$ The literature refers to different types of efficiency of which, the most common are technical, allocative, and scale efficiencies. The allocative efficiency measures a production unit's success in choosing an optimal set of inputs with a given set of input prices while technical efficiency concept is associated with the production frontier, which measures the unit's success in producing maximum output from a given set of inputs. Scale efficiency is associated with the right production size.
} 
DEA is an example of non-parametric efficiency measurement tool that offers several advantages. In addition to not requiring any assumption regarding the relationship between the inputs and the outputs, it is well designed to accommodate multiple input and output technologies. In contrast to most commonly used parametric techniques such as the Stochastic Frontier Approach, DEA offers the possibility to consider multiple outputs without requiring any assumptions on the relationship between these outputs. The DEA method is based on two relatively weak assumption: convexity and free disposability. ${ }^{5}$

In this study, DEA is applied to assess the efficiency with which school resources are utilized to deliver learning outcomes. Figure 3 illustrates the efficiency analysis using the DEA method. Let's assume that schools use one input $X$ (school resources) to produce a single output $Y$ (learning outcome). The frontier represents the maximum amount of output that can be produced given different levels of the input $X$. Schools on the frontier are considered relatively efficient while those below the frontier are considered relatively inefficient. For instance, a given school uses $x_{0}$ to produce $y_{0}$ and is at point $A$ in the figure. Since point $A$ is below the frontier, this school is considered inefficient. If this school was efficient, it could have achieved a higher level of output $\left(\delta y_{0}\right.$ with $\left.1 \leq \delta<+\infty\right)$ with the same amount of resources $\left(x_{0}\right)$. This corresponds to point B on the frontier. This means that $\delta y_{0}-y_{0}$ is the additional quantity of output that could be produced in the absence of inefficiencies. The distance to the frontier, captured by $\delta$, is a measure of inefficiency and reflects the ability of each school to translate their input into output.

Figure 3 Illustration of efficiency measurement with DEA

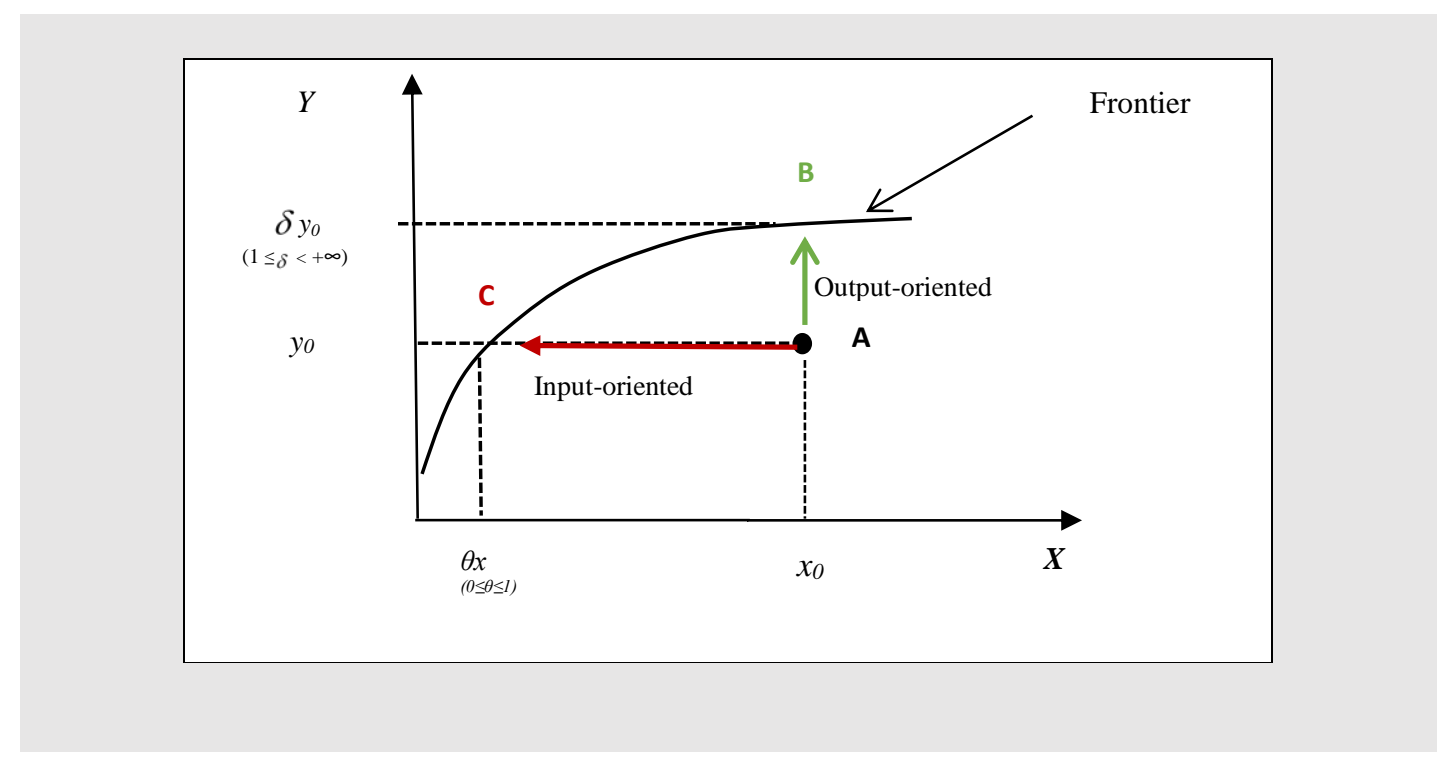

Among the existing DEA models, the most commonly used ones are the CCR (Charnes et al., 1978) and the BCC (Banker et al., 1984) models. The BCC model assumes variable returns to scale, while the CCR

\footnotetext{
${ }^{5}$ Although the DEA method has several benefits, it also suffers from certain drawbacks. For example, the assumption that the production set is convex has been criticized and some approaches have been suggested to relax the convexity assumption (Boussemart et al., 2009; Briec and Peypoch, 2010 or Leleu et al., 2012). However, relaxing the convexity assumption comes with some complexities that would not necessarily add some value to this paper. In fact, convexity assumes that a convex combination of the inputs would still be able to produce a similar convex combination of the outputs. In the context of efficiency analysis in education, the convexity assumption seems to not be too strong, especially when applied to assess technical efficiency.
} 
model is associated with a constant returns to scale assumption. Resource allocation across schools in francophone Africa is done without any consideration of returns to scale. In most countries, school resources are officially allocated depending on needs. For these reasons, the CCR model seems to better approximate the process of resource allocation and education service delivery in francophone Africa.

Figure 3 shows that for a relatively inefficient school, there are two avenues in reaching the frontier: inputoriented technology (in this case input needs to decrease, outputs remaining constant) and output-oriented technology (output needs to increase, inputs remaining constant). In the education system, there are multiple non-discretionary inputs. For instance, while it could appear relatively easy to decrease the number of textbooks, inputs such as infrastructure could not be influenced in the short term. In addition, given the lack of resources, it may not be convenient to suggest a decrease of inputs for improved efficiency. Therefore, an output-oriented efficiency model is applied in this study.

DEA being a deterministic method, all deviations from the frontier (including measurement errors) are attributable to inefficiency. This may represent an important drawback especially when applied to learning assessment data, which usually, may be subject to some measurement errors. To address this issue, the bootstrapping DEA method introduced by Simar and Wilson (2000) is applied.

Some environmental factors can play a role in school efficiency. To investigate the role of these variables on the efficiency, a second stage regression is performed. As described by Simar and Wilson (2007), the DEA data generating process being unknown, the most common regression techniques may not be appropriate. The Simar and Wilson (2007) double-bootstrapping technique is then applied to investigate the effects of school environmental factors on school efficiency.

This paper also aims to investigate the relationship between school resources and students' learning outcomes taking into consideration school efficiency. Given the hierarchical structure of the data, students being enrolled in schools and schools belonging to different countries, a multi-level econometric regression is applied. ${ }^{6}$ Two levels are considered: countries and schools. Using the efficiency results from the DEA model, schools are grouped by decile depending on their efficiency levels. To determine the influence of efficiency in the relationship between students' scores and school resources, two models are compared. In a 'base model', schools are used as a level variable along with the countries. In a second model, the school variable is replaced by efficiency deciles. The variations in the results of these two models reflect the contribution of efficiency to the relationship between student's learning outcomes and school resources. The model using the efficiency as a level variable is later estimated separately for two groups of schools: the 'highest inefficiency schools' (inefficiency in the highest tercile) and the 'lowest inefficiency schools' (inefficiency in the lowest tercile).

\section{Data}

\section{Input and output variables for the DEA model}

To investigate the efficiency in the delivery of quality education in francophone Africa, PASEC (Programme d'Analyse des Systèmes de la CONFEMEN) 2014 learning assessment data are used. Since 1991, PASEC has conducted more than 35 learning assessments in francophone developing countries. In 2012, PASEC put in place a plan to collect comparable learning assessments in francophone Africa. In 2014, 10 West and Central African countries participated in this PASEC assessment, yielding a crosscountry comparable learning assessment database. ${ }^{7}$ The PASEC 2014 dataset is comprehensive and includes some data collected from students, teachers and school directors.

${ }^{6}$ See Greene (2017) for details about multi-level models

${ }^{7}$ See PASEC website: http://www.pasec.confemen.org/ 
The selection of input and output variables in the current study is based on the literature but constrained by the availability of data. Based on the education production function literature (Hanushek,1986 and 2008), it can be assumed that schools use three key resources to deliver education: (i) teachers, (ii) learning materials and (iii) infrastructure. A total of 6 input variables are selected as proxies for teachers (teachers' salary level, education level) ${ }^{8}$, textbooks (proportion of students with reading and mathematics textbooks), infrastructure (PASEC infrastructure quality index) and pedagogical resources (PASEC pedagogical resource index). The PASEC reading and mathematics average score by school is included as two output variables. Table 1 provides descriptive statistics of the data used.

Table 1: Descriptive Statistics: Efficiency analysis

\begin{tabular}{|c|c|c|c|c|c|}
\hline & $\mathrm{N}$ & Mean & Std. Dev. & Min & Max \\
\hline \multicolumn{6}{|l|}{ Inputs } \\
\hline \multicolumn{6}{|l|}{ Teachers } \\
\hline Teacher's level of education & 1,807 & 5.72 & 1.73 & 1.00 & 13.00 \\
\hline Teachers salary level & 1,807 & 5.79 & 1.69 & 1.00 & 11.00 \\
\hline \multicolumn{6}{|l|}{ Infrastructure } \\
\hline PASEC infrastructure quality index & 1,807 & 49.44 & 5.91 & 23.13 & 80.42 \\
\hline \multicolumn{6}{|l|}{ Learning materials } \\
\hline Proportion of students with reading textbooks & 1,807 & 0.81 & 0.16 & 0.05 & 1.00 \\
\hline Proportion of students with mathematics textbooks & 1,807 & 0.74 & 0.19 & 0.04 & 1.00 \\
\hline PASEC pedagogical resources index & 1,807 & 50.10 & 5.63 & 19.62 & 79.23 \\
\hline \multicolumn{6}{|l|}{ Outputs } \\
\hline Average reading score & 1,807 & 497 & 45 & 325 & 689 \\
\hline Average mathematics score & 1,807 & 497 & 47 & 324 & 666 \\
\hline \multicolumn{6}{|l|}{ Environmental variables } \\
\hline School type (Private) & 1531 & 0.20 & 0.40 & 0.00 & 1.00 \\
\hline Area (Urban) & 1531 & 0.33 & 0.47 & 0.00 & 1.00 \\
\hline Quality of teaching environment (index) & 1531 & 49.81 & 10.19 & 13.98 & 108.79 \\
\hline Local infrastructure index & 1531 & 48.55 & 9.81 & 34.73 & 66.56 \\
\hline Class size (students/number of effective seat) & 1531 & 2.15 & 2.47 & 0.00 & 28.00 \\
\hline Teachers' gender (Male) & 1531 & 0.78 & 0.41 & 0.00 & 1.00 \\
\hline Community engagement index & 1531 & 49.72 & 9.77 & 8.46 & 81.34 \\
\hline Share of girls & 1531 & 0.47 & 0.09 & 0.00 & 0.79 \\
\hline Instruction time & 1531 & 30 & 8 & 0 & 75 \\
\hline Community engagement index & 1531 & 49.72 & 9.77 & 8.46 & 81.34 \\
\hline
\end{tabular}

With schools being the unit of observation (or the decision-making units, DMUs), each school is compared to other schools within the same country. This comparison is used to build the frontier of best practices or frontier of efficiency. As already described, schools on the frontier are the most efficient in translating their resources into learning outcomes. Schools below the frontier are considered relatively inefficient. Based on

\footnotetext{
${ }^{8}$ The number of teachers may have been a relevant input indicator but almost all classrooms involved in the assessment have 1 teacher. So, the number of teachers has been excluded from the set of input variables.
} 
the distance to this frontier, a relative inefficiency score is computed. The inefficiency score varies between 1 and $+\infty$ ( 1 for those on the frontier and higher than 1 for the others). ${ }^{9}$ The lower the inefficiency score, the more efficient is the school when compared with the other schools in the same country. It is assumed that the most important inputs for learning outcomes are taken into consideration. Changes in the variables or in the sample of schools may lead to different results.

\section{Data for the multi-level regression}

To investigate the relationship between school resources and students' learning outcomes and the influence of inefficiency in this relationship, a multi-level regression will be estimated using a set of regressors. These regressors broadly capture teachers' characteristics, the availability of learning materials, infrastructure, as well as control variables for students' gender and socio-economic background. Table 2 presents the descriptive statistics of the data used for the multi-level regressions.

Table 2 Descriptive Statistics: multilevel regression

\begin{tabular}{|c|c|c|c|c|c|}
\hline Variable & Obs & Mean & Std. Dev. & Min & Max \\
\hline Reading Score & 28,569 & 494.98 & 96.60 & 79.73 & 858.72 \\
\hline Mathmatics Score & 28,569 & 497.24 & 99.47 & 90.90 & 912.21 \\
\hline School type (public) & 28,569 & 0.82 & 0.39 & 0.00 & 1.00 \\
\hline Area (urban) & 28,569 & 0.33 & 0.47 & 0.00 & 1.00 \\
\hline \multicolumn{6}{|l|}{ Teachers } \\
\hline Teacher: formal education level & 28,569 & 5.68 & 2.85 & 1.00 & 13.00 \\
\hline Teacher: additional training & 28,569 & 0.81 & 0.39 & 0.00 & 1.00 \\
\hline Teacher: female & 28,569 & 0.23 & 0.42 & 0.00 & 1.00 \\
\hline Teacher: teaching experience & 28,569 & 11.83 & 7.96 & 0.00 & 47.00 \\
\hline Teacher: salary level & 28,569 & 3.13 & 0.66 & 1.00 & 4.00 \\
\hline Teacher: regular salary & 28,569 & 0.94 & 0.23 & 0.00 & 1.00 \\
\hline \multicolumn{6}{|c|}{ School facilities \& infrastructures } \\
\hline Library & 28,569 & 0.06 & 0.24 & 0.00 & 1.00 \\
\hline Clinic & 28,569 & 0.02 & 0.14 & 0.00 & 1.00 \\
\hline Pharmacy & 28,569 & 0.25 & 0.44 & 0.00 & 1.00 \\
\hline Water & 28,569 & 0.35 & 0.48 & 0.00 & 1.00 \\
\hline Electricity & 28,569 & 0.26 & 0.44 & 0.00 & 1.00 \\
\hline Toilet & 28,569 & 0.76 & 0.42 & 0.00 & 1.00 \\
\hline Free learning materials & 28,569 & 0.44 & 0.50 & 0.00 & 1.00 \\
\hline Walls & 28,569 & 0.27 & 0.45 & 0.00 & 1.00 \\
\hline \multicolumn{6}{|l|}{ Students } \\
\hline Sex (Male) & 28,569 & 0.53 & 0.50 & 0.00 & 1.00 \\
\hline Socio-economic status index & 28,569 & 49.03 & 9.82 & 17.54 & 88.34 \\
\hline
\end{tabular}

\footnotetext{
${ }^{9}$ The score $(\boldsymbol{\delta})$ in the DEA output-oriented model is higher than 1 and captures inefficiency. An equivalent efficiency score $(0<1 / \delta<1)$ can be calculated and interpreted as efficiency in percentage terms.
} 


\section{Results}

\section{Efficient utilization of school resources for learning}

Efficiency is measured using the input and output variables described above. To allow each school to be compared with the appropriate benchmarks within the same countries, a different DEA model is estimated for each country. The DEA results show that the average inefficiency score in the 10 PASEC countries is 1.25 (Table 3). Alternatively, the efficiency level is $80 \% .{ }^{10}$ There is a problem in the efficient use of school resources in PASEC schools. Comparing all schools with the most efficient schools in each country shows that resources used to improve learning outcomes are relatively wasted. In the 10 PASEC countries, the reading and mathematics learning scores may have been about $25 \%$ higher if all schools were as efficient as the most efficient schools in each of the PASEC countries.

Table 3 Descriptive statistics of the efficiency scores ${ }^{11}$

\begin{tabular}{cccccc}
\hline Variable & Obs & Mean & Std. Dev. & Min & Max \\
\hline Efficiency & 1,807 & 1.25 & 0.16 & 1.01 & 2.11 \\
\hline
\end{tabular}

PASEC countries have different abilities to translate their resources into learning outcomes (Figure 4). Inefficiency varies among schools within the same country and on average across countries. On average, Togo, Cameroon and Chad seem to have the highest school inefficiency on average, while Benin, Niger and Burkina Faso have the lowest school inefficiency. In addition to being one of the countries with the highest inefficiency level on average, Cameroon is also one of the countries with the highest inequality among schools in terms of inefficiency. Overall, within each country, the least inefficient schools tend to register higher average achievements in mathematics and reading. This suggests that inefficiency in resource utilization could be one of the reasons for poor learning outcomes.

Figure 4 Average school inefficiency score by country

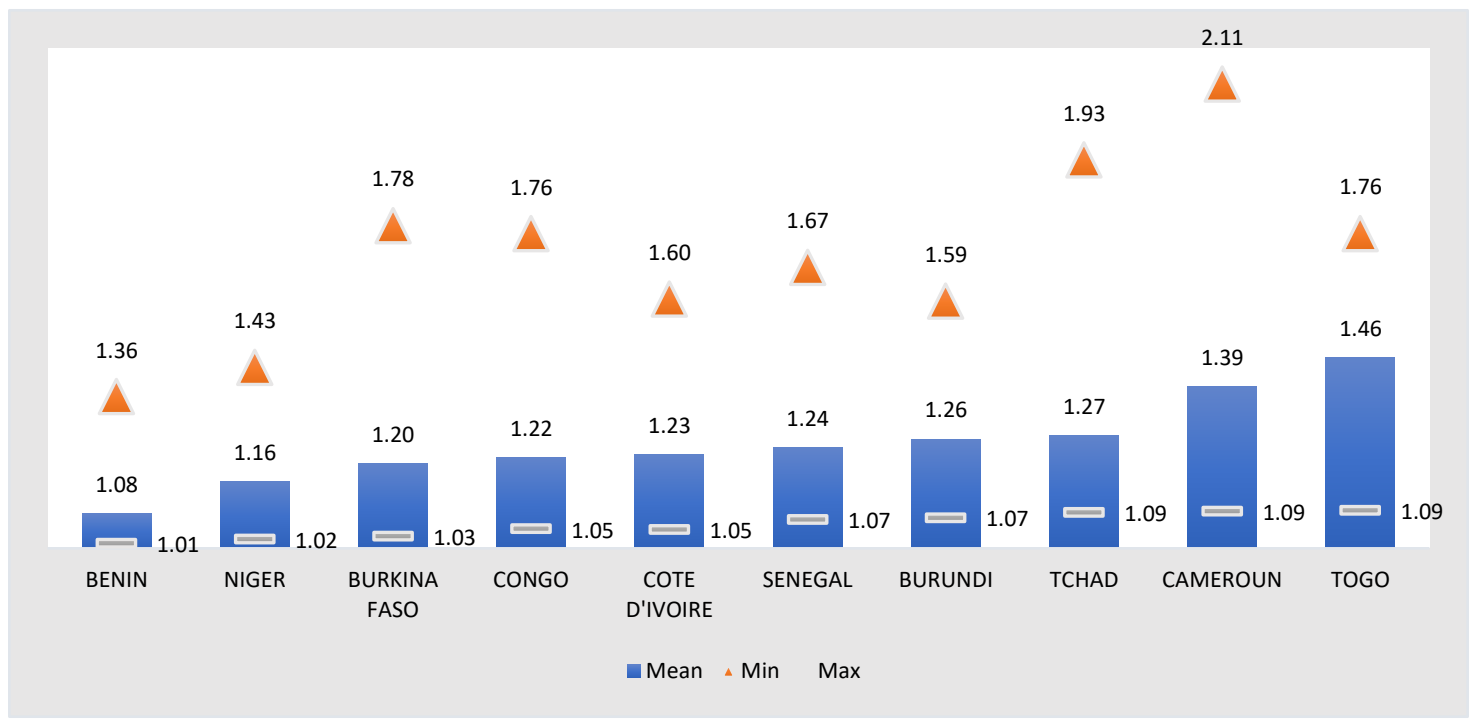

\footnotetext{
${ }^{10}$ As mentioned above the inefficiency score in the output oriented is given by $\delta$ with $1<\delta<+\infty$. $1 / \delta$ is an equivalent way to present the results in percentage terms.

${ }^{11}$ Descriptive statistics of the inefficiency scores by country are presented in Table 7
} 
Reducing inefficiency is particularly important for reaching the SDG 4.1.1 target on the proportion of primary school completers meeting minimum proficiency levels in reading and mathematics. If all schools in the PASEC countries were efficient (or as efficient as the most efficient schools), and if the increase in the average learning score at school level was equivalently reflected in the learning scores at the student level, $75.7 \%$ and $76.4 \%$ of primary education completers would have achieved the minimum proficiency levels in reading and mathematics respectively. This represents a substantial improvement when compared with the actual $39.2 \%$ and $40.2 \%$ of students achieving a minimum proficiency level in reading and in mathematics respectively. Although lacking resources could generally result in lower student performance, inefficiency in the use of the existing resources could be another important reason for poor learning outcomes in some francophone African countries.

Figure 5 Improvement in the proportion of students achieving minimum proficiency level in reading and mathematics

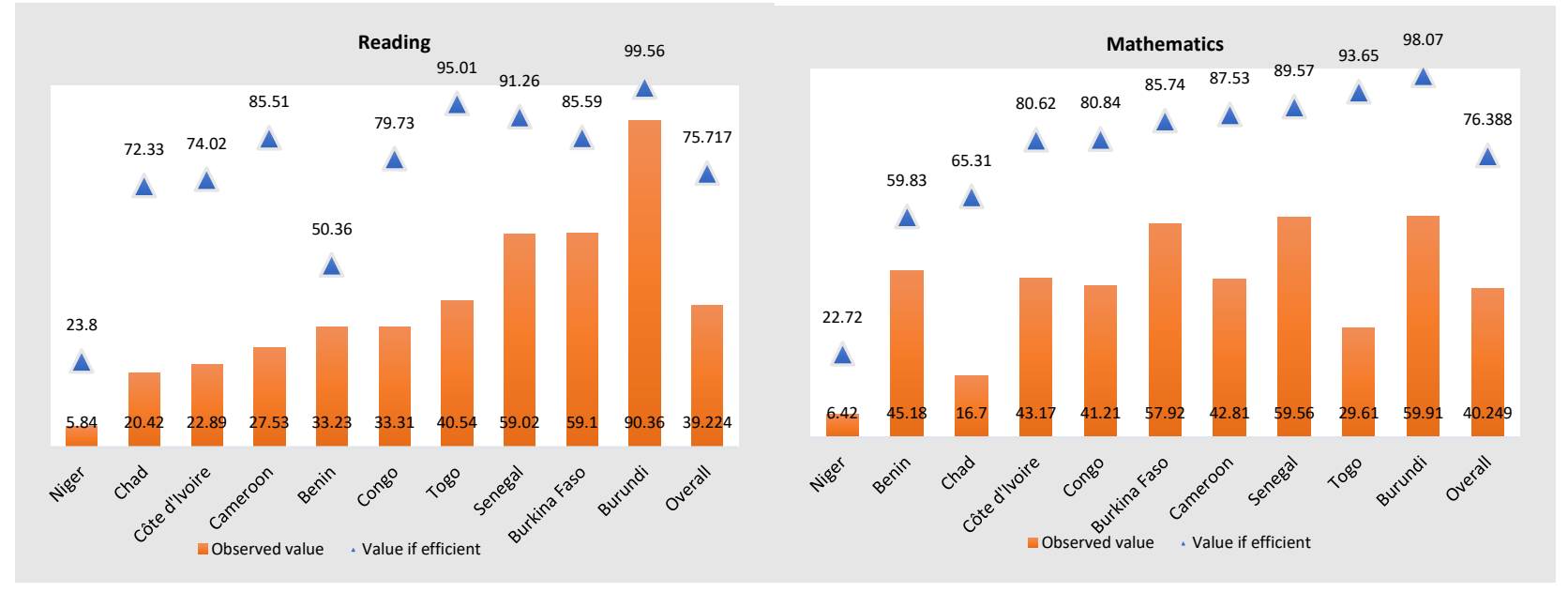

Sensitivity analysis and efficiency drivers

Measuring inefficiency by comparing schools within the same countries may have contributed to underestimating the inefficiency level previously calculated. To provide a sensitivity analysis, the inefficiency scores are re-calculated, comparing schools across countries. In addition to allowing each school to be compared with other schools across countries, the Simar and Wilson (2007) doublebootstrapping technique is applied to allow inefficiency drivers to be investigated and to be taken into consideration in the efficiency measurement (Table 4). Overall, being a private school and being located in an urban area negatively contributes to inefficiency. Inefficiency is mainly driven by teachers and students' absenteeism, shorter teaching time, and limited quality of the teaching environment as reported by teachers. ${ }^{12}$ After controlling for the environmental variables and allowing schools to be compared across countries, the average inefficiency score significantly increases. ${ }^{13}$ This suggests that learning outcomes

\footnotetext{
${ }^{12}$ A correlation test shows a negative correlation between inefficiency and other variables such as the quality of the infrastructure in the areas of the schools. Schools with a functioning management committee, a free canteen, as well as schools where the community is involved in school management through parent's association register a lower inefficiency level.

${ }^{13}$ Descriptive statistics of the inefficiency scores when environmental variables are controlled for are presented in Table 8.
} 
should substantially increase for all schools to be as efficient as the most efficient schools across all the 10 PASEC countries.

Table 4: Second Stage DEA regression

\begin{tabular}{lrrr}
\hline & $\begin{array}{l}\text { Lower } \\
\text { Marginal } \\
\text { Eependent variable: inefficiency scores }\end{array}$ & $\begin{array}{l}\text { Confidence } \\
\text { Intervall (5\%) }\end{array}$ & $\begin{array}{l}\text { Upper } \\
\text { Confidence } \\
\text { Intervall (95 \%) }\end{array}$ \\
\hline Intercept & 1.6786 & 1.5198 & 1.8331 \\
School type (Private) & -0.1712 & -0.2268 & -0.1131 \\
Area (Urban) & -0.1401 & -0.1956 & -0.0851 \\
Quality of teaching environment & -0.0022 & -0.0040 & -0.0004 \\
Instruction time & -0.0070 & -0.0096 & -0.0044 \\
Students' absenteeism & 0.2799 & 0.1725 & 0.3807 \\
Teachers' absenteeism & 0.0191 & 0.0115 & 0.0262 \\
Observations & 1531 & & \\
\hline
\end{tabular}

The dependent variable is the inefficiency score $(\delta$ ). A negative marginal effect shows a negative effect on inefficiency (or a positive effect on the efficiency) while a positive marginal effect illustrates a positive effect on inefficiency (or a negative effect on the efficiency). Only variables that are significant at a $10 \%$ level are presented in this table. The full list of environmental variables included in the second stage DEA regression is presented in Table 1.

\section{School resources for improved learning outcomes at student's level: does inefficiency matter?}

A series of multi-level regressions is performed to investigate the role of inefficiency in the relationship between school resources and learning outcomes at the level of the students. Model 1 and 3 in Table 5 are the 'base model' in which school dummies are used as the level variables. These models include random intercepts for each school to control for school effects on students learning outcomes. In models 2 and 4 ('inefficiency model') deciles of the school inefficiency scores are used as the level variables. This means that these models include controls for school inefficiency. Overall, the effects of teacher training, teacher experience and salary level on learning outcomes are higher when inefficiency is taken into consideration. In addition, AIC and BIC statistics show that the econometric model becomes more accurate when controlling for inefficiency. ${ }^{14}$ This suggests that efficiency could play an important role in strengthening the relationship between learning outcomes on the one hand and teachers and some elements of school facilities on the other hand.

\footnotetext{
14 The Power of the Chi-2 test is higher when inefficiency deciles are used as a level variable rather, than school
} dummies. 
Table 5: Econometric results: controlling for inefficiency

\begin{tabular}{|c|c|c|c|c|}
\hline Dependent variable: PASEC scores & $\begin{array}{l}\text { (Model 1) } \\
\text { Reading; } \\
\text { Base-model }\end{array}$ & $\begin{array}{c}\text { (Model 2) } \\
\text { Reading; } \\
\text { Inefficiency-model }\end{array}$ & $\begin{array}{c}\text { (Model 3) } \\
\text { Maths; Base-model }\end{array}$ & $\begin{array}{c}\text { (Model 4) } \\
\text { Maths; } \\
\text { Inefficiency-mode }\end{array}$ \\
\hline School type (public) & $\begin{array}{c}-36.42 * * * \\
(3.806)\end{array}$ & $\begin{array}{c}-32.36 * * * \\
(1.504)\end{array}$ & $\begin{array}{c}-32.68 * * * \\
(3.904)\end{array}$ & $\begin{array}{c}-29.28 * * * \\
(1.524)\end{array}$ \\
\hline Area (urban) & $\begin{array}{l}34.72 * * * \\
(3.307)\end{array}$ & $\begin{array}{l}30.07 * * * \\
(1.283)\end{array}$ & $\begin{array}{l}22.95 * * * \\
(3.394)\end{array}$ & $\begin{array}{c}17.89 * * * \\
(1.300)\end{array}$ \\
\hline Teachers & & & & \\
\hline Teacher: formal education & $\begin{array}{c}1.731 * * * \\
(0.448)\end{array}$ & $\begin{array}{c}1.923 * * * \\
(0.175)\end{array}$ & $\begin{array}{l}1.311 * * * \\
(0.460)\end{array}$ & $\begin{array}{l}1.430 * * * \\
(0.177)\end{array}$ \\
\hline Teacher: additional training & $\begin{array}{c}3.532 \\
(3.284)\end{array}$ & $\begin{array}{l}5.211 * * * \\
(1.246)\end{array}$ & $\begin{array}{l}5.858^{*} \\
(3.370)\end{array}$ & $\begin{array}{c}8.222 * * * \\
(1.263)\end{array}$ \\
\hline Teacher: female & $\begin{array}{l}18.84 * * * \\
(3.697)\end{array}$ & $\begin{array}{c}15.57 * * * \\
(1.392)\end{array}$ & $\begin{array}{l}17.41 * * * \\
(3.799)\end{array}$ & $\begin{array}{c}14.07 * * * \\
(1.411)\end{array}$ \\
\hline Teacher: teaching experience & $\begin{array}{c}0.200 \\
(0.163)\end{array}$ & $\begin{array}{c}0.163 * * * \\
(0.0617)\end{array}$ & $\begin{array}{c}0.112 \\
(0.167)\end{array}$ & $\begin{array}{c}0.112 * \\
(0.0625)\end{array}$ \\
\hline Teacher: salary level & $\begin{array}{c}0.928 \\
(1.953)\end{array}$ & $\begin{array}{c}0.772 \\
(0.748)\end{array}$ & $\begin{array}{c}0.485 \\
(2.004)\end{array}$ & $\begin{array}{c}0.366 \\
(0.758)\end{array}$ \\
\hline Teacher: regular salary & $\begin{array}{l}25.15 * * * \\
(5.197)\end{array}$ & $\begin{array}{l}25.88^{* * * *} \\
(2.057)\end{array}$ & $\begin{array}{l}29.92 * * * \\
(5.330)\end{array}$ & $\begin{array}{l}29.32 * * * \\
(2.084)\end{array}$ \\
\hline School facilities & & & & \\
\hline Library & $\begin{array}{c}19.94 * * * \\
(5.300)\end{array}$ & $\begin{array}{l}18.18 * * * \\
(1.987)\end{array}$ & $\begin{array}{l}18.61 * * * \\
(5.438)\end{array}$ & $\begin{array}{c}16.45^{* * * *} \\
(2.013)\end{array}$ \\
\hline Pharmacy & $\begin{array}{l}10.76^{* * * *} \\
(3.386)\end{array}$ & $\begin{array}{c}11.56^{* * *} \\
(1.304)\end{array}$ & $\begin{array}{l}14.01 * * * \\
(3.476)\end{array}$ & $\begin{array}{c}14.43 * * * \\
(1.321)\end{array}$ \\
\hline Wall & $\begin{array}{l}15.01 * * * \\
(3.620)\end{array}$ & $\begin{array}{l}15.93 * * * \\
(1.370)\end{array}$ & $\begin{array}{c}12.43 * * * \\
(3.716)\end{array}$ & $\begin{array}{c}13.52 * * * \\
(1.388)\end{array}$ \\
\hline Water & $\begin{array}{c}10.76^{* * * *} \\
(3.159)\end{array}$ & $\begin{array}{l}9.939 * * * \\
(1.189)\end{array}$ & $\begin{array}{l}7.942 * * \\
(3.242)\end{array}$ & $\begin{array}{l}7.509 * * * \\
(1.205)\end{array}$ \\
\hline Electricity & $\begin{array}{l}20.82 * * * \\
(3.695)\end{array}$ & $\begin{array}{l}18.48 * * * \\
(1.383)\end{array}$ & $\begin{array}{l}21.39 * * * \\
(3.792)\end{array}$ & $\begin{array}{l}19.19 * * * \\
(1.401)\end{array}$ \\
\hline Toilets & $\begin{array}{l}9.589 * * * \\
(3.189)\end{array}$ & $\begin{array}{l}7.947 * * * \\
(1.250)\end{array}$ & $\begin{array}{c}11.57 * * * \\
(3.272)\end{array}$ & $\begin{array}{l}9.970 * * * \\
(1.266)\end{array}$ \\
\hline Free learning material & $\begin{array}{c}10.06^{* * * *} \\
(3.724)\end{array}$ & $\begin{array}{l}9.063 * * * \\
(1.434)\end{array}$ & $\begin{array}{c}12.39 * * * \\
(3.833)\end{array}$ & $\begin{array}{c}11.29 * * * \\
(1.454)\end{array}$ \\
\hline Students & & & & \\
\hline Sex (Male) & $\begin{array}{l}2.484 * * * \\
(0.770)\end{array}$ & $\begin{array}{c}0.111 \\
(0.905)\end{array}$ & $\begin{array}{c}6.490 * * * \\
(0.772)\end{array}$ & $\begin{array}{c}4.676^{* * * *} \\
(0.917)\end{array}$ \\
\hline Socio-economic status index & $\begin{array}{l}0.627 * * * \\
(0.0600)\end{array}$ & $\begin{array}{l}1.166^{* * * *} \\
(0.0591)\end{array}$ & $\begin{array}{c}0.114 * \\
(0.0602)\end{array}$ & $\begin{array}{l}0.609 * * * \\
(0.0599)\end{array}$ \\
\hline Observations & $\begin{array}{c}28,712 \\
\text { Wald } \\
\text { chi2(17) } \\
1379.20 \\
\text { Prob }>\text { chi2 } \\
=\quad 0.0000 \\
\text { AIC: } \\
322745.7 \\
\text { BIC: } \\
322919.2\end{array}$ & $\begin{array}{c}28,712 \\
\text { Wald chi2(17) }= \\
8559.64 \\
\text { Prob }>\text { chi } 2= \\
0.0000 \\
\text { AIC: } 330395.4 \\
\text { BIC: } 330569.0\end{array}$ & $\begin{array}{c}28,712 \\
\text { Wald chi2(17) } \\
864.55 \\
\text { Prob }>\text { chi } 2= \\
0.0000 \\
\text { AIC: } 322914.2 \\
\text { BIC: } 323087.7\end{array}$ & $\begin{array}{c}28,712 \\
\text { Wald chi2(17) } \\
5322.20 \\
\text { Prob }>\text { chi } 2 \\
0.0000 \\
\text { AIC: } 331157.6 \\
\text { BIC: } 331331.2\end{array}$ \\
\hline
\end{tabular}

Another way to capture the influence of school inefficiency in the relationship between school resources and learning outcomes, is to estimate the same econometric model (inefficiency model in table 5) separately for the group of lowest inefficient schools (lowest inefficiency tercile) and that of the highest inefficient schools (highest inefficiency tercile). Results show that the influence of teachers' education and training, school facilities such as the presence of library, quality of infrastructures, toilets, electricity and clean water 
are strongly associated with learning outcomes in the group of lowest inefficient schools (Table 6). In the group of highest inefficient schools, teacher training is not associated with better learning outcomes. Teachers being associated with one of the highest school cost categories, higher spending on teachers may not drive better education outcomes in high inefficient schools. In other terms, teacher policies need to be tailored for the school specific context and may take into consideration, the efficiency in the use of the existing resources including teachers. However, allocating more experienced teachers to the highest inefficient schools seem to be associated with better learning outcomes. This may suggest that one way to mitigate the risk of inefficient use of resources is to deploy more experienced teachers to the most inefficient schools. PASEC data show that teachers in rural areas have on average, lower years of experience in teaching compared to teachers in urban areas. The most inefficient schools being mostly located in rural areas, this finding implies some changes in teacher deployment policies.

Table 6: Econometric results: comparing the effect of school resources on learning outcomes in the group of highest inefficient schools VS lowest inefficient schools

\begin{tabular}{|c|c|c|c|c|}
\hline $\begin{array}{l}\text { Dependent variable: } \\
\text { PASEC scores }\end{array}$ & $\begin{array}{l}\text { (Model 1) } \\
\text { Reading: highest } \\
\text { inefficiency } \\
\text { group }\end{array}$ & $\begin{array}{c}\text { (Model 2) } \\
\text { Reading: lowest } \\
\text { inefficient group }\end{array}$ & $\begin{array}{c}\text { (Model 3) } \\
\text { Maths: highest } \\
\text { inefficiency } \\
\text { group }\end{array}$ & $\begin{array}{c}\text { (Model 4) } \\
\text { Maths : lowest } \\
\text { inefficiency } \\
\text { group }\end{array}$ \\
\hline School type (public) & $\begin{array}{c}-33.19^{* * * *} \\
(2.520)\end{array}$ & $\begin{array}{l}-32.22 * * * \\
(2.759)\end{array}$ & $\begin{array}{c}-31.34 * * * \\
(2.624)\end{array}$ & $\begin{array}{c}-25.64 * * * \\
(2.730)\end{array}$ \\
\hline Area (urban) & $\begin{array}{c}36.85 * * * \\
(2.270)\end{array}$ & $\begin{array}{c}30.44 * * * \\
(2.191)\end{array}$ & $\begin{array}{c}24.38 * * * \\
(2.363)\end{array}$ & $\begin{array}{c}17.17 * * * \\
(2.170)\end{array}$ \\
\hline \multicolumn{5}{|l|}{ Teachers } \\
\hline $\begin{array}{l}\text { Teacher: formal } \\
\text { education }\end{array}$ & $\begin{array}{c}1.130 * * * \\
(0.303)\end{array}$ & $\begin{array}{c}1.383 * * * \\
(0.291)\end{array}$ & $\begin{array}{l}0.574 * \\
(0.316)\end{array}$ & $\begin{array}{c}1.246^{* * *} \\
(0.288)\end{array}$ \\
\hline $\begin{array}{l}\text { Teacher: additional } \\
\text { training }\end{array}$ & -2.321 & $14.55^{* * * *}$ & 1.233 & $21.62 * * *$ \\
\hline & $(2.232)$ & $(2.190)$ & $(2.324)$ & $(2.169)$ \\
\hline Teacher: female & $\begin{array}{c}15.31 * * * \\
(2.626)\end{array}$ & $\begin{array}{l}9.206 * * * \\
(2.275)\end{array}$ & $\begin{array}{c}15.69 * * * \\
(2.734)\end{array}$ & $\begin{array}{c}6.411 * * * \\
(2.255)\end{array}$ \\
\hline $\begin{array}{l}\text { Teacher: teaching } \\
\text { experience }\end{array}$ & $0.444 * * *$ & $-0.340 * * *$ & $0.379 * * *$ & $-0.361^{* * *}$ \\
\hline Teacher: salary level & $\begin{array}{c}(0.114) \\
1.200 \\
(1.311)\end{array}$ & $\begin{array}{c}(0.102) \\
0.637 \\
(1.362)\end{array}$ & $\begin{array}{c}(0.118) \\
0.620 \\
(1.365)\end{array}$ & $\begin{array}{l}(0.101) \\
-0.128 \\
(1.349)\end{array}$ \\
\hline Teacher: regular salary & $\begin{array}{c}25.58 * * * \\
(3.249)\end{array}$ & $\begin{array}{c}43.25 * * * \\
(4.341)\end{array}$ & $\begin{array}{c}33.77 * * * * \\
(3.382)\end{array}$ & $\begin{array}{c}43.98 * * * \\
(4.299)\end{array}$ \\
\hline \multicolumn{5}{|l|}{ School facilities } \\
\hline Library & $\begin{array}{c}18.60 * * * \\
(3.137)\end{array}$ & $\begin{array}{c}29.73 * * * \\
(3.680)\end{array}$ & $\begin{array}{c}20.07 * * * \\
(3.266)\end{array}$ & $\begin{array}{c}22.60 * * * \\
(3.643)\end{array}$ \\
\hline pharmacy & $\begin{array}{l}21.16 * * * \\
(2.500)\end{array}$ & $\begin{array}{l}5.277 * * \\
(2.066)\end{array}$ & $\begin{array}{c}22.33 * * * \\
(2.603)\end{array}$ & $\begin{array}{l}5.917 * * * \\
(2.045)\end{array}$ \\
\hline Wall & $\begin{array}{c}10.98 * * * \\
(2.429)\end{array}$ & $\begin{array}{c}21.51 * * * \\
(2.349)\end{array}$ & $\begin{array}{c}8.188^{* * * *} \\
(2.528)\end{array}$ & $\begin{array}{c}19.87 * * * \\
(2.326)\end{array}$ \\
\hline Water & $\begin{array}{c}2.279 \\
(2.126)\end{array}$ & $\begin{array}{c}18.55 * * * * \\
(1.974)\end{array}$ & $\begin{array}{l}-0.356 \\
(2.213)\end{array}$ & $\begin{array}{l}17.73 * * * \\
(1.954)\end{array}$ \\
\hline Electricity & $\begin{array}{c}14.53 * * * \\
(2.464)\end{array}$ & $\begin{array}{c}20.72 * * * \\
(2.322)\end{array}$ & $\begin{array}{l}21.31 * * * \\
(2.565)\end{array}$ & $\begin{array}{l}18.49 * * * \\
(2.299)\end{array}$ \\
\hline Toilets & $\begin{array}{c}10.63 * * * \\
(2.049)\end{array}$ & $\begin{array}{c}10.65^{* * * *} \\
(2.258)\end{array}$ & $\begin{array}{c}18.82 * * * \\
(2.133)\end{array}$ & $\begin{array}{c}9.933 * * * \\
(2.237)\end{array}$ \\
\hline Free learning material & $\begin{array}{l}-2.911 \\
(2.621)\end{array}$ & $\begin{array}{l}13.91 * * * \\
(2.653)\end{array}$ & $\begin{array}{l}-0.268 \\
(2.730)\end{array}$ & $\begin{array}{c}14.55^{* * * *} \\
(2.634)\end{array}$ \\
\hline Students & & & & \\
\hline Sex (Male) & $\begin{array}{l}0.573 \\
(1.576)\end{array}$ & $\begin{array}{l}-1.776 \\
(1.559)\end{array}$ & $\begin{array}{c}7.479 * * * \\
(1.641)\end{array}$ & $\begin{array}{l}-0.378 \\
(1.543)\end{array}$ \\
\hline $\begin{array}{l}\text { Socio-economic status } \\
\text { index }\end{array}$ & $1.245^{* * *}$ & $1.088 * * *$ & $0.720 * * *$ & $0.447 * * *$ \\
\hline & $(0.104)$ & $(0.0981)$ & $(0.108)$ & $(0.0971)$ \\
\hline Observations & 9,265 & 9,761 & 9,265 & 9,761 \\
\hline
\end{tabular}




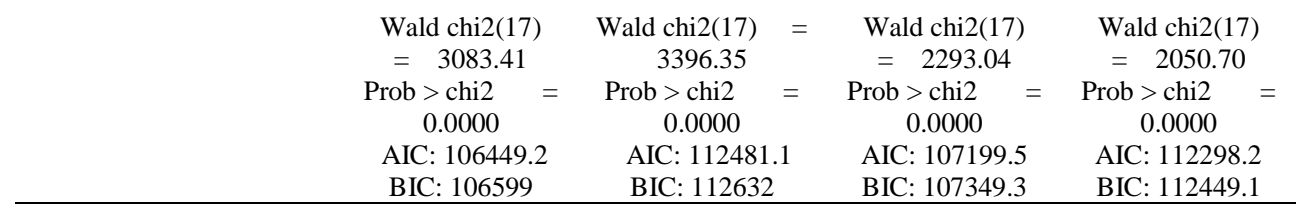

\section{Conclusion and discussion}

The lack of resources is often highlighted as one of the most important causes of poor learning outcomes. However, this may not be the case for all schools. More resources may not lead to improvement in learning outcomes in the presence of inefficiencies. The purpose of this study is to assess the efficiency with which school resources are translated into learning outcomes in the 10 PASEC countries. The average inefficiency score is 1.25 , suggesting that school resources may be wasted because of some inefficiencies in the education system. Alternatively, the learning scores could potentially improve by $25 \%$ if all schools become relatively efficient. This may offer significant implications for the proportion of students achieving minimum proficiency levels. If all schools were as efficient as the most efficient schools in each country, the proportion of primary completers achieving minimum proficiency levels in reading and mathematics might have improved by approximately 36 percentage points. Public schools located in rural areas are more likely to be inefficient. However, teachers' and students' attendance, teaching time and the quality of the learning environment are associated with lower inefficiency.

Better teacher policy may play a key role in improving the efficiency in resource utilization and learning. Results from this paper show that investing in teachers (training or increased teacher remuneration) in the most inefficient schools may not contribute to learning outcomes. Increased spending on teachers would not drive better learning outcomes if resources available at school level are not efficiency utilized. Efficiency drivers at the school level must be identified and further investments in inefficient schools would need to address efficiency issues. Less experienced teachers are often deployed in rural areas where inefficiencies are higher. However, allocating more experienced teachers to the most inefficient schools appears to be positively correlated with learning outcomes. This finding may imply some changes in teacher deployment policies.

Improving learning requires tailored policies taking into consideration inefficiency in the use of resources at school level. Overall, results show that since resources are relatively poorly utilized in the least efficient schools, increasing resources without any improvement in the efficiency level may not be an effective way to promote learning outcomes. Particularly, there are some schools in the category of low efficient schools with an average performance below the minimum proficiency level. ${ }^{15}$ Prioritizing improvement in the efficiency in the lowest efficient schools would be a key strategy to promote learning outcomes. Some of the schools have low performance in learning but are using their resources efficiently to reach the observed learning outcomes. Increasing school resources in low performing schools with the highest efficiency levels could be another effective way for improved learning outcomes. ${ }^{16}$ Overall, improving learning outcomes requires targeted policies that will ensure that the right resource is allocated to the right school and resources are efficiently used to promote learning outcomes.

\footnotetext{
${ }^{15}$ See Figure 6 in the Annex section

${ }^{16}$ Returns to scale are overall increasing in this category of schools
} 


\section{References}

Abagi, O., \& Odipo, G. (1997). Efficiency of primary education in Kenya:. Institute of Policy Analysis and Research.

Agasisti, T. (2014). How does schools' efficiency look like across Europe? An empirical analysis of Germany, Spain, France, Italy and UK using OECD PISA 2012 data. Società Italiana di Economia Pubblica.

Aristovnik, A. (2012) The relative efficiency of education and R\&D expenditures in the new EU member states. Journal of Business Economics and Management, 13(5), 832-848.

Ashton, D., Green, F., James, D. \& Sung, J. (1999). Education and Training for Development in East Asia: The political economy of skill formation in East Asian newly industrialised economies.

Ashton, D., Green, F., Sung, J., \& James, D. (2002). The Evolution of Education and Training Strategies in Singapore, Taiwan and S. Korea: A development model of skill formation. Journal of Education and Work, 15(1), 5-30.

Banker, R. D., Charnes, A., \& Cooper, W. W. (1984). Some Models for Estimating Technical and Scale Inefficiencies in Data Envelopment Analysis. Management Science, 30(9), 1078-1092.

Birdsall, N., Bruns, B., \& Maden, J. (2016). Learning data for better policy: A global agenda (Policy Paper No. 096). Retrieved from Center for Global Development website: https://www.cgdev.org/sites/default/files/learning-data-better-policy1.pdf

Bloom, D. E., Canning, D., Chan, K., \& Luca, D. L. (2014). Higher Education and Economic Growth in Africa. International Journal of African Higher Education, 1(1).

Boussemart, J., Briec, W., Peypoch, N., \& Tavéra, C. (2009). $\alpha$-Returns to scale and multi-output production technologies. European Journal of Operational Research, 197(1), 332-339.

Campos, J. E., \& Root, H. L. (2003). The key to the Asian miracle: Making shared growth credible. Washington, DC: The Brookings Institution.

Charnes, A., Cooper, W., \& Rhodes, E. (1978). Measuring the efficiency of decision making units. European Journal of Operational Research, 2(6), 429-444.

Charnes, A., Cooper, W. W., Learner, D. B., \& Phillips, F. Y. (1985). Management Science and Marketing Management. Journal of Marketing, 49(2), 93-105.

Charnes, A., Cooper, W. W., Golany, B., Schmitz, E., \& Sherman, H. (1986). Developments in Efficiency Analysis.

Chavas, J., \& Briec, W. (2010). On economic efficiency under non-convexity. Economic Theory, 50(3), 671-701.

Cohn, E., \& Addison, J. T. (1998). The Economic Returns to Lifelong Learning in OECD Countries. Education Economics, 6(3), 253-307.

Essid, H., Ouellette, P. \& Vigeant, S. (2013) Small is not that beautiful after all: measuring the scale efficiency of Tunisian high schools using a DEA-bootstrap method. Applied Economics, 45(9),

Farrell, M. J. (1957). The Measurement of Productive Efficiency. Journal of the Royal Statistical Society. Series A (General), 120(3), 253.

Friedlander, E. W., Arshan, N., Zhou, S., \& Goldenberg, C. (2018). Lifewide or School-Only Learning: Approaches to Addressing the Developing World's Learning Crisis. American Educational Research Journal, 1-35. 
Fuller, B., \& Clarke, P. (1994). Raising school effects while ignoring culture? Local conditions and the influence of classroom tools, rules, and pedagogy. Review of Educational Research, 64(1), 119157.

Geo-Jaja, M. A. (2004). Decentralisation And Privatisation Of Education In Africa: Which Option For Nigeria? International Review of Education/Internationale Zeitschrift fr Erziehungswissenschaft/ Revue inter, 50(3), 309-325.

Gershberg, A., and D. Winkler. 2004. "Education Decentralization in Africa: A Review of Recent Policy and Practice." In Building State Capacity in Africa: New Approaches, Emerging Lessons, edited by B. Levy and S. Kpundeh, 323-56. Washington, DC: World Bank Institute

Glewwe, P., Kremmer, M., Moulin, S., \& Zitzewitz, E. (2004). Retrospective vs. prospective analyses of school inputs: The case of flip charts in Kenya. Journal of Development Economics, 74, 251-268.

Gove, A., \& Cvelich, P. (2011). Early reading: Igniting education for all (A report by the Early Grade Learning Community of Practice). Retrieved from Research Triangle Institute International website: https://www.rti.org/sites/default/files/resources/early-reading-report-revised.pdf

Greene, W. H. (2017). Econometric Analysis. London, England: Pearson.

Gyimah-Brempong, K., Paddison, O., \& Mitiku, W. (2006). Higher education and economic growth in Africa. Journal of Development Studies, 42(3), 509-529.

Hanushek, E. (1986). The Economics of Schooling: Production and Efficiency in Public Schools. Journal of Economic Literature, 24(3), 1141-1177.

Hanushek, E., \& Woessman, L. (2008) The Role of Cognitive Skills in Economic Development. Journal of Economic Literature, 46(3), 607-68.

Hanushek, E., \& Benson, C. S. (1994). Making schools work: Improving performance and controlling costs. Washington, DC: Brookings Institution.

Hanushek, E. A. (2008). Education Production Functions. The New Palgrave Dictionary of Economics, 15.

Hanushek, E. A., Jamison, D. T., Jamison, J. A., \& Woessmann, L. (2008). Education and Economic Growth: It's not Just Going to School but Learning That Matters. Education Next, 8(2), 62.

Hanushek, E. A., \& Woessman, L. (2013). The Role of International Assessments of Cognitive Skills in the Analysis of Growth and Development. In M. Von Davier, E. Gonzalez, I. Kirsch, \& K. Yamamoto (Authors), The role of international large-scale assessments: Perspectives from technology, economy, and educational research economists (pp. 47-65).

Heyneman, S. (2003). Education, social cohesion, and the future role of international organizations. Peabody Journal of Education, 78 (3). pp. 25 - 38.

Kuruvilla, S. (2007). Adjusting to globalization through skills development strategies. In D. A. Rondinelli \& J. M. Heffron (Eds.), Globalization and change in Asia (pp. 127-148).

Lee, V. E., \& Zuze, T. L. (2011). School Resources and Academic Performance in Sub-Saharan Africa. Comparative Education Review, 55(3), 369-397.

Leleu, H., Moises, J., \& Valdmanis, V. (2012). Optimal productive size of hospital's intensive care units. International Journal of Production Economics, 136(2), 297-305.

Lockheed, M. E., \& Hanushek, E. (1988). Improving Educational Efficiency in Developing Countries: what do we know?. Compare: A Journal of Comparative and International Education, 18(1), 21 38. 
McGinn, N. F., Snodgrass, D. R., Kim, Y. B., Kim, S., \& Kim, Q. (1980). Harvard East Asian Monographs: Vol. 90. Education and development in Korea. Retrieved from Harvard University Press website: https://www.kdevelopedia.org/Resources/all/education-development-korea-04201310310128762.do\#.XFAx2eSWwdU

Michaelowa, K. (2001). Primary education quality in francophone sub-saharan africa: Determinants of learning achievement and efficiency considerations. World Development, 29(10), 1699-1716.

OECD. (2018), "Indicator A3 How does educational attainment affect participation in the labour market?". In Education at a Glance 2018: OECD Indicators (pp. 70-86).

Perelman, S., \& Santin, D. (2011) Measuring educational efficiency at student level with parametric stochastic distance functions: An application to Spanish PISA results. Education Economics, 19(1), 29-49.

Pritchett, L., \& Filmer, D. (1999). What education production functions really show: A positive theory of education expenditures. Economics of Education Review, 18(2), 223-239.

Psacharopoulos, G., \& Patrinos, H. A. (2004) Returns to investment in education: a further update, Education Economics, 12(2), 111-134.

Psacharopoulos, G., \& Patrinos, H. A. (2004.). Human Capital and Rates of Return. in: International Handbook on the Economics of Education, chapter 1. Edward Elgar Publishing.

Samoff, J. (1999). No teacher guide, no textbooks, no chairs: Contending with crisis in african education. Retrieved from https://files.eric.ed.gov/fulltext/ED443769.pdf

Simar, L., \& P. W. Wilson. (2000). A General Methodology for Bootstrapping in Nonparametric Frontier Models. Journal of Applied Statistics (27)6, 779-802

Simar, L., \& Wilson, P. W. (2007). Estimation and inference in two-stage, semi-parametric models of production processes. Journal of Econometrics, 136(1), 31-64.

Schultz, T. (1961). Investment in Human Capital. The American Economic Review, 51(1), 1-17.

Shepard, L. (2005). Linking formative assessment to scaffolding. Educational Leadership, 63(3), 66-70.

Stiggins, R. J. (2002). Assessment crisis: The absence of assessment for learning. Phi Delta Kappan, 758765.

Schultz, T. W. (1980). The economics of being poor. Bulletin of the Atomic Scientists, 36(9), 32-37, DOI: $10.1080 / 00963402.1980 .11458781$

Trostel, P., Walker, I., \& Woolley, P. (2002). Estimates of the economic return to schooling for 28 countries. Labour Economics, 9(1), 1-16. DOI: 10.1016/s0927-5371(01)00052-5

UNESCO. (2013). The global learning crisis: Why every child deserves a quality education [Brochure]. Retrieved from https://unesdoc.unesco.org/ark:/48223/pf0000223826

UNESCO. (2014). EFA global monitoring report 2013-2014.

UNESCO. (2015). EFA global monitoring report: Education for all 2000-2015: Achievements and challenges.

Vandenberg, M. (2008). An Inclusive Environment. London, England: Routledge.

Vegas, E., \& Coffin, C. (2015). When education expenditure matters: An empirical analysis of recent international data. Comparative Education Review, 59(2), 289-304.

William, D. (2011). What is assessment for learning? Studies in Educational Evaluation, 37(1), 3-14. 
Witte, K. D., \& López-Torres, L. (2017). Efficiency in education: a review of literature and a way forward. Journal of the Operational Research Society, 68(4), 339-363.

World Bank. (2017). DataBank: Education statistics - all indicators. Retrieved from World Bank http://databank.worldbank.org/data/reports.aspx?source=education-statistics- -allindicators\&preview $=$ on\# 


\section{Annexes}

Table 7 Inefficiency score comparing schools within each country

\begin{tabular}{lcccc}
\hline \multicolumn{1}{c}{ PAYS } & Number of schools & Mean & Min & Max \\
\hline Benin & 165 & 1.08 & 1.36 & 1.01 \\
Burkina Faso & 182 & 1.20 & 1.78 & 1.03 \\
Burundi & 180 & 1.26 & 1.59 & 1.07 \\
Cameroun & 266 & 1.39 & 2.11 & 1.09 \\
Congo & 163 & 1.22 & 1.76 & 1.05 \\
Cote d'Ivoire & 169 & 1.23 & 1.60 & 1.05 \\
Niger & 176 & 1.16 & 1.43 & 1.02 \\
Senegal & 160 & 1.24 & 1.67 & 1.07 \\
Chad & 157 & 1.27 & 1.93 & 1.09 \\
Togo & 189 & 1.46 & 1.76 & 1.09 \\
Overall & 1,807 & 1.25 & 2.11 & 1.01 \\
\hline
\end{tabular}

Table 8 Inefficiency score when controlling for environmental variables and allowing cross-country comparison

\begin{tabular}{lcccc}
\hline & Number of schools & Mean & Min & Max \\
\hline Benin & 145 & 1.93 & 1.60 & 2.11 \\
Burkina Faso & 171 & 1.89 & 1.53 & 2.16 \\
Burundi & 172 & 1.84 & 1.57 & 2.04 \\
Cameroun & 173 & 1.87 & 1.51 & 2.10 \\
Congo & 122 & 1.85 & 1.55 & 2.18 \\
Cote d'Ivoire & 165 & 1.95 & 1.62 & 2.23 \\
Niger & 153 & 1.91 & 1.59 & 2.13 \\
Senegal & 130 & 1.94 & 1.67 & 2.16 \\
Chad & 119 & 1.86 & 1.53 & 2.19 \\
Togo & 181 & 1.85 & 1.53 & 2.07 \\
Overall & 1531 & 1.89 & 1.51 & 2.23 \\
\hline
\end{tabular}


Figure 6 Efficiency level and average reading score

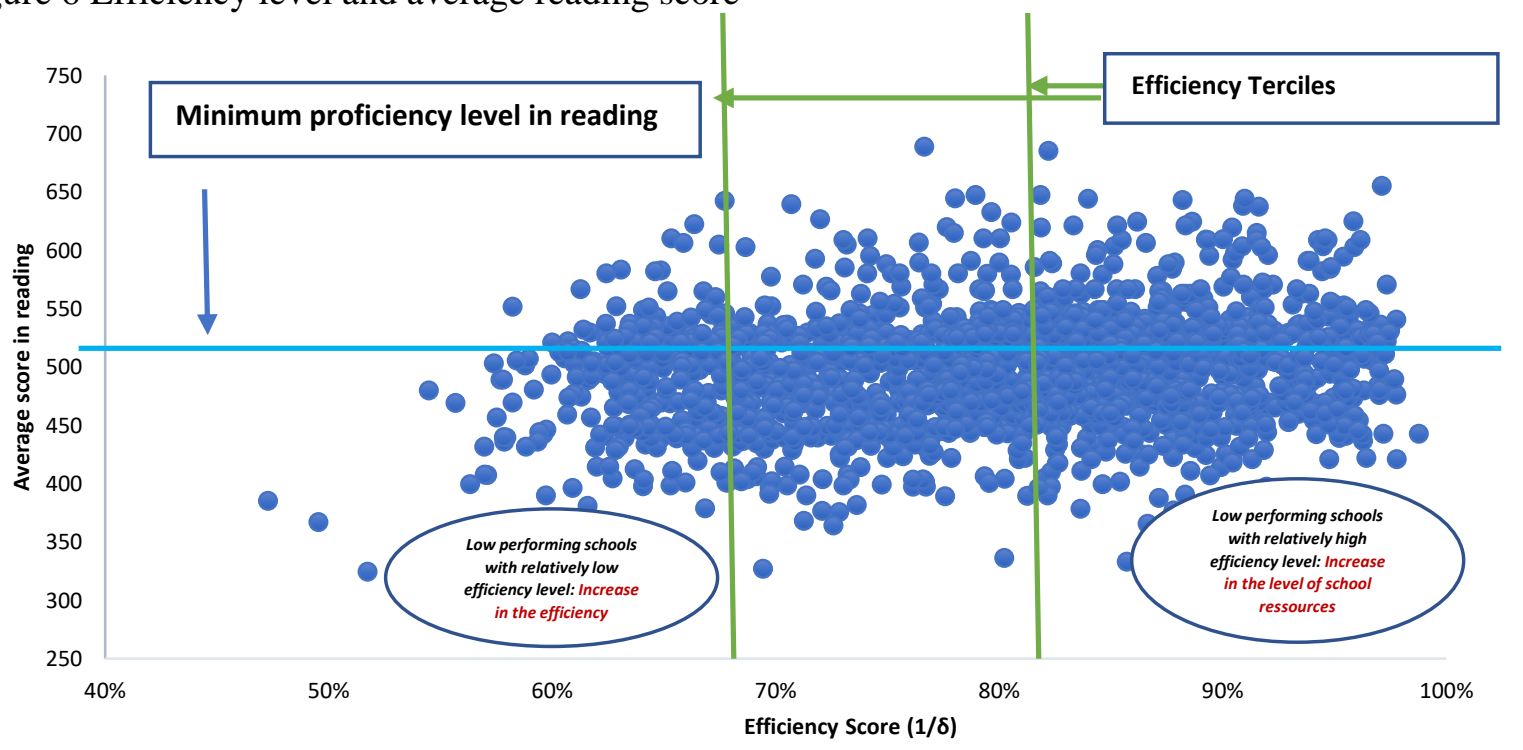

